\title{
NIH drops survey on discrimination, claiming questions 'ill-designed'
}

Washington. The US National Institutes of Health (NIH) have abandoned an equalopportunities survey that had been sent out to each of their 16,000 staff members. Officials say the survey was stopped because employees complained about its design. But they admit that some returns were assessed before the decision was made to abandon the exercise.

The aborted study, planned to cost $\$ 80,000$, was intended to help the NIH Task Force on Fairness in Employment Practices to prepare an action plan to counter allegations of sexual and racial discrimination at NIH (see Nature 363, 105; 1993).

Staff were asked about unfair employment practices at NIH. But most of the 14 questions concerned the effectiveness of NIH's Equal Opportunities Office, whose manager has just been replaced.

Sandy Chamblee, acting deputy director for science policy at NIH and chairwoman of the task force, said that the task force decided to rescind the survey because it "didn't want to be side-tracked on the secondary issue" of the survey's validity.

The questionnaire was sent out on 1 July with a covering letter from Harold Varmus, the director of NIH, stating that summary results would be shared with all staff and asking for a response within five days. But after extensive debate within the task force, Varmus sent a second letter on 18 August saying that the survey would not proceed,

\section{Tsunami experts left high and dry}

Tokyo. As a result of a territorial dispute with Russia, the Japanese government has blocked Japanese specialists in tsunami - the large waves that follow earthquakes from participating in an international survey of the Russian-held southern Kuril Islands.

The islands were hit by tsunami last month after a large earthquake off the coast of Japan's northern island of Hokkaido. Tsunami up to five metres high swept over the southern Kuril Islands after the earthquake struck on 4 October and several Russian fishermen lost their lives. Tsunami also hit Japan's Pacific coast, but the waves were only one to two metres high and caused little damage (see Nature 371, 549; 1994).

Communicating by electronic mail, tsunami specialists in Japan, Russia and the United States quickly laid plans for a survey of the islands. Y. Tsuji of the Earthquake Research Institute of Tokyo University was to have led a team of three Japanese scientists that would have joined at least four Russians and one US scientist in Yuzhno-Sakhalinsk in Sakhalin on $\mathbf{1 6}$ October, before proceeding to the islands.

Tsuji received an official invitation from Aleksey Ivaschenko, deputy director of the Russian Institute of Marine Geology and Geophysics, and says that everything was ready for obtaining visas for his team from the Russian Embassy in Tokyo. But when he contacted the Japanese Ministry of Education, Science and Culture to obtain official approval, he was told that the trip would be "illegal" and he and the other Japanese scientists "could lose their jobs".

\section{IMAGE UNAVAILABLE FOR COPYRIGHT REASONS}

After-effects of last month's earthquake.

The ministry told Tsuji that university scientists are government officials and are therefore banned from visiting the islands. Russia occupied the islands at the end of the Second World War and Japan has been lobbying hard in recent years to have them returned.

Apart from preventing Japanese participation in the survey, which Tsuji says has proceeded without them, the territorial dispute has made it difficult for the survey scientists to reach the islands. These are only a few tens of kilometres from the northern tip of Hokkaido and it would make a lot of sense for the survey team to approach them by ship or by air from Hokkaido.

But according to one of the survey participants, Harry Yeh of the University of Washington in the United States, this idea was never taken seriously because of the territorial dispute. Instead, the team had to be organized at the Russian Tsunami Warning Centre in Sakhalinsk, $400 \mathrm{~km}$ away from the islands.

David Swinbanks and that "no analysis will be conducted of the response received thus far".

The lateness of the rescission has led some NIH staff to suggest that the survey had been abandoned because the task force did not like the results. Anne Thomas, a spokeswomen for NIH, dismisses this suggestion as "ridiculous". But she concedes that the task force did indeed see "a small number" of the returns before deciding to abandon the survey.

$\mathrm{NIH}$ staff were asked to send the questionnaires to Research Applications, a Maryland market research company, whose fee was to be $\$ 77,843$. NIH said it "is now looking at how that price might come down since the analysis was not completed".

Members of the task force are being tight-lipped about the rescission decision, referring enquiries to Chamblee, who in turn chose to answer detailed questions through Thomas. Thomas said that objectors to the survey had made six specific criticisms.

For example, some objectors claim that the survey was biased, with some of the questions assuming that unfair treatment did exist at NIH, such as "What should NIH do to reduce unfair treatment?". It also directed answers by requiring respondents to pick from nine types of "unfair treatment", leaving no room for additional comment.

Some staff apparently objected to being forced to answer "yes" or "no" to certain questions, even though only one out of 14 "Do you think you have been unfairly treated in your present job?" - required such an answer.

In addition, Thomas said that there were some "sweeping, but non-specific" complaints about the survey and others that "it didn't give the opportunity to reflect on reverse discrimination, where people feel they are discriminated against because they are not part of a minority group".

Some observers claim that this last complaint suggests the NIH may be experiencing a backlash against its equal opportunities work. Issues of both race and sex discrimination have recently been given a higher public profile than some managers and staff feel is appropriate.

But NaomiChurchill, who replaced Diane Armstrong as manager of the NIH Equal Opportunities Office in September, says she is not discouraged. "I haven't encountered much resistance," says Churchill. "Most people here want to do the right thing."

Earlier this month, Harold Varmus met congressional staff to discuss sexual discrimination at NIH. He told them that he did not much like the questionnaire and had sent it out "against his better judgement" before rescinding it.

Colin Macilwain 